\title{
JARINGAN SYARAF TIRUAN \\ MENGGUNAKAN ALGORITMA BACKPROPAGATION UNTUK MEMPREDIKSI PRESTASI SISWA
}

\author{
Fatmi Zola1)., Gunadi Widi Nurcahyo' ${ }^{2)}$., Julius santony ${ }^{3)}$ \\ ${ }^{1}$ Teknik Komputer Jaringan, SMK Negeri 2 Pinggir, BTN Puri Perawang Blok C, No. \\ 37 Tualang, fatmizola82@gmail.com \\ ${ }^{2,3}$ Jurusan Teknik Informatika, Universitas Putra Indonesia YPTK Padang.
}

\begin{abstract}
ABSTRAK
Sekolah Menengah Kejuruan Negeri 1 Bunga Raya (SMK N 1 Bunga Raya) merupakan sekolah kejuruan dalam bidang Multi Kompetensi. Saat ini terdapat 265 orang siswa dengan 5 jurusan (bidang) diantaranya Teknik Komputer Jaringan (TKJ),Teknik Sepeda Motor (TSM), Akuntansi, Teknik Pengolahan Hasil Pertanian (TPHP), Agrobisnis Tanaman Perkebunan (ATP).Untuk meningkatkan prestasi siswa, maka sekolah memberikan beasiswa berupa beasiswa prestasi akademik. Sistem Jaringan Syaraf Tiruan menggunakan metode Backpropagation yang diterapkan dalam penelitian ini untuk prediksi prestasi siswa, dan diharapkan dapat membantu memecahkan masalah pemberian beasiswa terhadap siswa yang berprestasi. Diimplementasikan menggunakan Matlab sebagai software yang mendukung. Dengan nilai ujian Sekolah sebagai data pelatihan dan pengujiannya. Hasil dari pengujian dengan pola arsitektur 4-2-1, data menjadi dua bagian yaitu 20 data pelatihan dengan persentase error 95,6 \%. Dan 20 data pengujian dengan persentase error 100\%. Semakin kecil tingkat ketelitian error yang digunakan maka akan semakin kecil penyimpangan hasil Jaringan Syaraf Tiruan dengan target yang diinginkan.
\end{abstract}

Kata Kunci: Backpropagation, Prediksi, Jaringan Syaraf Tiruan, Software, Matlab

\section{ABSTRACT}

Vocational High School Negeri 1 Bunga Raya (SMK N 1 Bunga Raya) is a vocational school in the field of Multi Competency. Currently there are 265 students with 5 majors (field) including Computer Network Engineering (TKJ), Motorcycle Engineering (TSM), Accounting, Agricultural Processing Technique (TPHP), Plantation Agribusiness (ATP) .To improve student achievement, then schools provide scholarships in the form of academic achievement scholarships. Artificial Neural Network System using Backpropagation method applied in this research to predict student achievement, and expected to help solve the problem of giving scholarship to student achievement. Implemented using Matlab as a supportive software. With the value of School examination as training data and testing. The result of testing with architectural pattern 4-2-1, the data into two parts that is 20 training data with percentage error 95,6\%. And 20 test data with 100\% error percentage. The smaller the level of accuracy error used will be the smaller deviation results Artificial Neural Network with the desired target.

Keywords: Backpropagation, Prediction, Artificial Neural Network, Software, Matlab 


\section{PENDAHULUAN}

Prestasi Akademik merupakan suatu istilah yang digunakan untuk menggambarkan pencapaian tingkat keberhasilan dalam bidang akademik. Prestasi ini didapatkan dari usaha belajar yang telah optimal. Prestasi Akademik dapat juga diartikan sebagai nilai rata-rata dari siswa dalam bidang akademik (Ghaemi, and Yazdanpanah, 2014). Prestasi akademik pada seorang siswa dapat dilihat dari nilai rapornya setiap akhir semester.

Sekolah Menengah Kejuruan Negeri 1 Bunga Raya (SMK N 1 Bunga Raya) merupakan sekolah kejuruan dalam bidang Multi Kompetensi. Saat ini terdapat 265 orang siswa dengan 5 jurusan (bidang) diantaranya Teknik Komputer Jaringan (TKJ), Teknik Sepeda Motor (TSM), Akuntansi, Teknik Pengolahan Hasil Pertanian (TPHP), Agrobisnis Tanaman Perkebunan (ATP). Untuk meningkatkan prestasi siswa, maka sekolah memberikan beasiswa berupa beasiswa prestasi akademik. Faktor yang menentukan siswa untuk mendapatkan beasiswa prestasi akademik, adalah nilai pelajaran yang terdapat dalam ujian nasional di atas kriteria ketuntasan mengajar (KKM), tetapi dalam pemberian beasiswa, pihak sekolah sering menemui permasalahan salah satunya kriteria penilaian yang kurang sesuai, adanya faktor kepentingan internal bagi beberapa pihak yang bersangkutan.

Penelitian ini memusatkan kepada pembuatan Jaringan Syaraf Tiruan (Artificial Neural Network) dalam memprediksi prestasi siswa dan menggunakan algoritma Backpropagation dalam penyelesaiannya. Jika selama ini penentuan prestasi siswa masih secara manual, maka penerapan ini merupakan konsep awal suatu metode untuk memprediksi siswa menggunakan alat bantu komputer yang didukung oleh Jaringan Syaraf Tiruan. Dengan sistem pemrosesan informasi yang didesain dengan menirukan cara kerja otak manusia dalam menyelesaikan suatu masalah, dengan melakukan proses belajar melalui perubahan bobot dan mampu melakukan pengenalan kegiatan berbasis data masa lalu yang akan dipelajari oleh Jaringan Syaraf Tiruan. Sehingga mempunyai kemampuan untuk memberikan keputusan.

Dengan Jaringan Syaraf Tiruan menggunakan metode Backpropagation komputer difungsikan sebagai alat untuk memprediksi prestasi siswa dengan tidak mempertimbangkan faktor-faktor lain penyebab kemerosotan atau peningkatan prestasi siswa, misalnya faktor lingkungan, fasilitas, motivasi belajar dan guru. Berdasarkan hal tersebutlah penulis mengangkat judul penelitian Jaringan Syaraf Tiruan Menggunakan Algoritma Backpropagation Untuk Memprediksi Prestasi Siswa.

\section{TINJAUAN PUSTAKA}

\subsection{Gambaran Umum Penerapan Jaringan Syaraf Tiruan}

Dengan berpedoman pada artikel di atas di sini penulis juga akan melakukan penelitian terhadap prestasi siswa dengan menggunakan Jaringan Syaraf Tiruan. Dan artikel di atas bisa nantinya dijadikan panduan dalam menyusun suatu penerapan Jaringan Syaraf Tiruan.

\subsection{Jaringan Syaraf Biologis}

Otak manusia terdiri atas $10^{11}$ sel syaraf yang berlaku sebagai prosesor. Sel syaraf ini berhubungan satu dengan yang lain membentuk suatu jaringan yang disebut jaringan syaraf. Proses yang terjadi yang terjadi dalam suatu sel syaraf merupakan proses elektrokimiawi. 


\subsection{Pengenalan Jaringan Syaraf Biologis}

Jaringan Syaraf Biologis adalah kumpulan sel syaraf (neuron). Neuron mempunyai tugas mengolah informasi. Komponen utama neuron dapat dikelompokkan menjadi 3 bagian (Puspitaningrum D., 2006), yaitu :

1. Dendrit bertugas untuk menerima informasi

2. Badan Sel (Soma) berfungsi sebagai tempat pengolahan informasi

3. Akson (Neurit) mengirimkan impuls-impuls ke sel syaraf lainnya

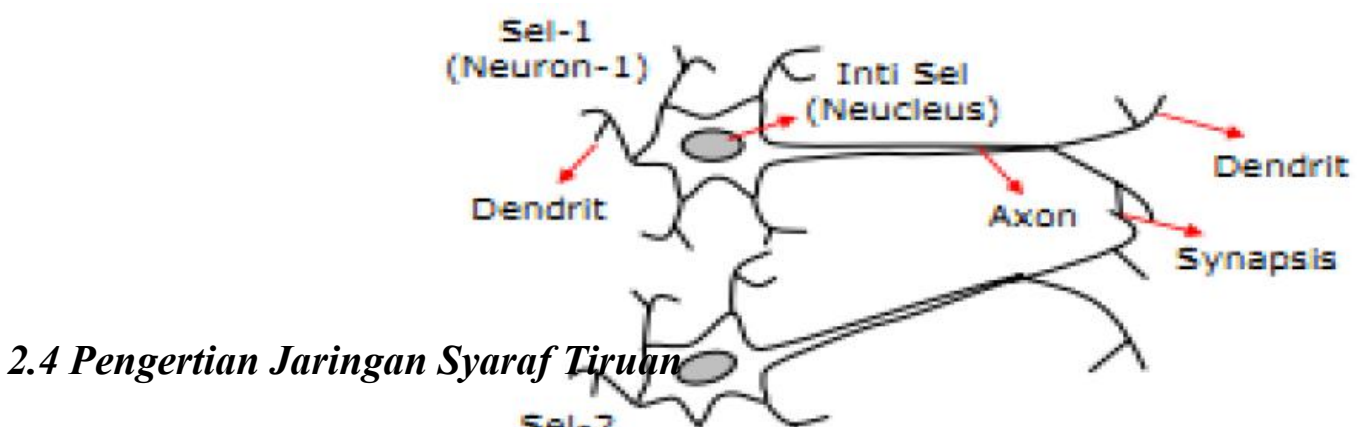

Jaringan Syaraf Tiruan atauedijencal, juga dengan Neural Network adalah suatu sistem Jaringan Syaraf Biologis yang ditiru oleh suatu metode komputasi yang digunakan untuk pemprosesan informasi. Ide dasarnya adalah mengadopsi cara kerja otak manusia yang memiliki karakteristik pengolahan paralel, mengolah unsur dalam jumlah besar dan toleransi kesalahan (Setiabudi D., 2015)

Jaringan Syaraf Tiruan menyebutkan 3 hal:

1. Pola hubungan antar neuron (disebut arsitektur jaringan).

2. Metode untuk menentukan bobot pengaitan (disebut metode pelatihan/ pembelajaran / algoritma).

3. Fungsi aktivasi (Pratama R.A., and Anifah L., 2016).

\section{1) 2.4.1 Konsep Dasar Jaringan Syaraf Tiruan}

Kerangka kerja Jaringan Syaraf Tiruan bisa dilihat dari jumlah lapisan (layer) dan jumlah Neuron. Neuron-neuron tersebut terkumpul di dalam lapisan-lapisan yang disebut neuron layers (Madontang Z.A., 2013). Lapisan-lapisan penyusun Jaringan Syaraf Tiruan tersebut dapat dibagi menjadi 3, yaitu :

1. Lapisan Input, node-node di dalam lapisan input disebut unit-unit. Unit-unit input menerima input dari dunia luar. Input yang dimasukkan merupakan penggambaran dari suatu masalah.

2. Lapisan Tersembunyi, node-node dalam lapisan ini disebut unit-unit tersembunyi. Di mana keluarannya tidak dapat secara langsung diamati.

Lapisan Output, node-node pada lapisan output disebut unit-unit output. Keluaran atau output dari lapisan ini merupakan output Jaringan Syaraf Tiruan terhadap suatu permasalahan. 


\section{2) 2.4.2 Arsitektur Jaringan Syaraf Tiruan}

Jaringan Syaraf Tiruan dirancang dengan menggunakan suatu aturan yang bersifat menyeluruh (general rule) di mana seluruh model jaringan memiliki konsep dasar yang sama. Arsitektur sebuah jaringan akan menentukan keberhasilan target yang akan dicapai karena tidak semua permasalahan dapat diselesaikan dengan arsitektur yang sama. Arsitektur Jaringan Syaraf Tiruan ada 3 (Wuryandari M,D., and Afrianto I., 2012), yaitu Jaringan lapis tunggal, jaringan dengan banyak lapisan, dan jaringan dengan lapisan kompetitif.

\section{3) 2.4.3 Mengaktifkan Jaringan Syaraf Tiruan}

Mengaktifkan Jaringan Syaraf Tiruan berarti mengaktifkan setiap neuron yang dipakai pada jaringan tersebut. Banyak fungsi yang dapat dipakai sebagai pengaktif, seperti fungsi-fungsi goniometri dan hiperbiliknya, fungsi unit step, seumlse, sigmoid, dan lain sebagainya. tetapi yang laxim digunakan adalah fungsi sigmoid, karena dianggap lebih mendeteksi kinerja sinyal pada otak manusia. Fungsi sigmoid memiliki nilai maksimum $=1$. Maka untuk pola yang targetnya $>1$, pola masukan dan keluaran harus terlebih dahulu ditransformasikan sehingga semua polanya memiliki range yang sama seperti fungsi sigmoid yang dipakai.

\section{4) 2.4.4 Algoritma Umum Jaringan Syaraf Tiruan}

Algoritma pembelajaran/pelatihan Jaringan Syaraf Tiruan (Puspitaningrum D., 2006), dimasukkan contoh pelatihan ke dalam Jaringan Syaraf Tiruan. Lakukan :

1. Inisialisasi bobot-bobot jaringan, set $\mathrm{i}=1$.

2. Masukkan contoh ke-i (dari sekumpulan contoh pembelajaran yang terdapat dalam set pelatihan) ke dalam jaringan pada lapisan input.

3. Cari tingkat aktivasi unit-unit output menggunakan algoritma aplikasi

If kinerja jaringan memenuhi standar yang ditentukan sebelumnya (memenuhi syarat bersih).

Then exit.

4. Update bobot-bobot dengan menggunakan aturan pembelajaran jaringan

5. If $\mathrm{i}=\mathrm{n}$, then reset $\mathrm{i}=1$,

Else $\quad \mathrm{i}=\mathrm{i}-1$,

Ke langkah 2.

Algoritma aplikasi inferensi Jaringan Syaraf Tiruan, dimasukkan sebuah contoh pelatihan ke dalam Jaringan Syaraf Tiruan. Lakukan :

1. Masukkan kasus ke dalam jaringan pada lapisan input.

2. Hitung tingkat aktifasi node-node jaringan.

3. Untuk jaringan koneksi umpan maju, jika tingkat aktivasi dari semua unit outputnya telah dikalkulasi, maka exit j jika tidak, kembali ke langkah 2. Jika jaringannya tidak stabil, maka exit dan fail.

Jadi dengan tingkat kemampuan yang sangat baik, beberapa aplikasi Jaringan Syaraf Tiruan sangaat cocok untuk diterapkan pada :

1. Klasifikasi, memilih suatu input data ke dalam satu kategori tertentu yang diterapkan.

2. Asosiasi, menggambarkan suatu objek secara keseluruhan hanya dengan sebuah bagian dari objek lain.

Self organizing, kemampuan untuk mengolah data-data input tanpa harus memiliki data sebagai target. 
Optimasi, menemukan suatu jawaban atau solusi yang paling baik sehingga seringkali dengan meminimalisasikan suatu fungsi biaya (optimizer).

\section{METODE PENELITIAN}

Pada penelitian ini diuraikan tentang metodologi dipakai dalam penelitian dan kerangka kerja penelitian yang digunakan dalam menyelesaikan penulisan mulai dari mendeskripsikan masalah, menganalisa permasalahan, menentukan tujuan, mempelajari literatur, pengumpulan data, analisis teknik Jaringan Syaraf Tiruan, pengujian algoritma Backpropagation, pengolahan data dengan Matlab R2011b, dan melakukan pengujian hasil. Kerangka kerja dibuat agar penelitian ini fokus dan terarah dalam mencapai tujuan penelitian.Metode penelitian menjelaskan pendekatan, rancangan kegiatan, ruang lingkup atau objek, bahan dan alat utama, tempat, teknik pengumpulan data, definisi operasional variabel penelitian, dan teknik analisis.

\section{HASIL DAN PEMBAHASAN}

Adapun proses algoritma Bacpropagation yang akan dilakukan dalam proses pelatihan algoritma Bacpropagation adalah menentukan parameter-parameter jaringan Bacpropagation yaitu menentukan input, menentukan ouput, menentukan bobot, menentukan bias dan menentukan threshold atau nila ambang $(\theta)$. Hal ini dapat di gambarkan melalui algoritma Bacpropagation berikut ini:

Algoritma proses Bacpropagation :

1. Ambil data

2. Iterasi Pertama Hingga Akhir Dari Data Pelatihan

3. Pelatihan dan Menentukan Parameter-parameter Jaringan

4. Kalkulasi Error Output

5. Proses Pengujian Algoritma Bacpropagation

6. Hasil.

Adapun data yang dijadikan objek penelitian ini adalah data Nilai Ujian Sekolah Siswa di SMK Negeri 1 Bunga Raya.

Tabel. 1 Data Input Pelatihan Prediksi Prestasi Siswa

\begin{tabular}{cccccc}
\hline No & \multicolumn{5}{c}{ Nilai Ujian } \\
Res & B. & B. & MTK & IPA & Rata-rata \\
& Ind & Ing & & & \\
1 & 8,60 & 8,60 & 8,50 & 8,50 & 8,55 \\
2 & 9,20 & 9,80 & 9,50 & 9,25 & 9,44 \\
3 & 8,40 & 8,60 & 8,50 & 8,40 & 8,48 \\
4 & 9,50 & 8,70 & 8,60 & 8,30 & 8,78 \\
5 & 8,50 & 8,60 & 8,80 & 8,60 & 8,63 \\
6 & 8,40 & 8,40 & 7,50 & 8,25 & 8,14
\end{tabular}




$\begin{array}{cccccc}7 & 8,60 & 8,20 & 8,25 & 8,25 & 8,33 \\ 8 & 9,00 & 8,60 & 7,50 & 8,75 & 8,46 \\ 9 & 8,50 & 7,80 & 8,00 & 7,80 & 8,03 \\ 10 & 8,80 & 9,00 & 7,50 & 8,50 & 8,45 \\ 11 & 8,60 & 8,60 & 7,75 & 8,00 & 8,24 \\ 12 & 8,80 & 8,80 & 7,50 & 8,75 & 8,46 \\ 13 & 8,80 & 8,40 & 7,75 & 8,50 & 8,36 \\ 14 & 7,95 & 7,90 & 7,50 & 7,68 & 7,76 \\ 15 & 8,39 & 8,52 & 8,23 & 8,29 & 8,36 \\ 16 & 8,80 & 8,20 & 7,50 & 8,00 & 8,13 \\ 17 & 8,60 & 8,25 & 7,90 & 8,05 & 8,20 \\ 18 & 8,80 & 8,40 & 7,50 & 8,50 & 8,30 \\ 19 & 6,55 & 6,70 & 7,50 & 7,80 & 7,14 \\ 20 & 8,00 & 8,00 & 8,00 & 7,50 & 7,88\end{array}$

Dari data sumber diatas dalam Jaringan Syaraf Tiruan dengan Bacpropagation ini akan dipakai fungsi aktivasi sigmoid karena pada fungsi aktivasi sigmoid nilai fungsinya terletak antara 0 dan 1 maka data tersebut ditranformasikan dulu. Data ditransformasikan ke interval yang lebih kecil. Proses normalisasi dapat ditentukan dengan menggunakan data sampel pada tabel 4.1 dapat dinormalisasikan dengan rumus transpormasi berikut:

$$
\mathrm{X}^{\prime}=\frac{0,8(X-b)}{(a+b)}+0,1
$$

Algoritma Propagasi balik adalah sebagai berikut:

1. Inisialisasi bobot

2. Tetapkan epoch maksimum, target, error, dan leraning rate

Langkah 0: Inisialisasi bobot dengan nilai random atau acak yang cukup kecil. Set learning rate $\alpha(0<\alpha<=1)$

Langkah 1: Selama kondisi berhenti masih belum terpenuhi, laksanakan langkah

sampai 9.

Langkah 2: Untuk tiap pasangan pelatihan,kerjakan langkah 3 sampai 8.

Feedforward:

Langkah 3: Setiap unit input Xj (dari unit ke-1 sampai unit ke- $n$ pada lapisan input) mengiriman sinyal input kesemua unit yang ada pada lapisan atasnya kelapisan atasnya (lapisan tersembunyi) :xi.

Langkah 4 : Pada setiap unit di lapisan tersembunyi Zj (dari unit ke-1 sampai unit ke-p; $1=1, \ldots, n ; j=1, \ldots \ldots, p)$ sinyal output lapisan tersembunyi dihitung dengan menerapkan fungsi aktivasi terhadap penjumlahan sinyal-sinyal input berbobot xi : 


$$
Z j=f\left(\boldsymbol{v}_{0 j}+\sum x_{i} \boldsymbol{v}_{i j}\right)_{i=1}^{n}
$$

Di mana:

$Z j \quad=$ unit tersembunyi ke-j

$F \quad=$ fungsi nonlinear

Voj $\quad=$ bias pada unit tersembunyi $-j$

$\sum x i=$ jumlah input $\mathrm{ke}-i$

$V i j=$ bobot ke- $j$

Kemudian dihitung nilai output dengan menggunakan fungsi aktifasi yang digunakan:

$$
z j=f\left(z_{-} \text {in } j\right)
$$

Di mana fungsi aktivasi yang digunakan adalah fungsi sigmoid biner yang mempunyai persamaan:

$$
f(x)=\frac{1}{1+\delta^{x}}
$$

Hasil fungsi tersebut dikirim ke semua neuron pada lapisan diatasnya.

Langkah 5: Setiap unit dilapisan output $y k$ (dari unit ke-1 sampai unit ke- $m, 1, \ldots ., \mathrm{n} k=1, \ldots .$. , $\mathrm{m}$ ) dihitung sinyal ouputnya dengan menerapkan fungsi aktivasi terhadap penjumlahan sinyal-sinyal input berbobot $z_{j}$ bagi lapisan ini :

$$
\begin{aligned}
& \mathrm{Y}_{\mathrm{k}}=f\left(\mathcal{W}_{o k}+\sum z_{j} \mathcal{W}_{j k}\right)_{i=1}^{p} \\
& \text { Di mana : } \\
& Y k \quad=\text { Unit output ke- } k \\
& f \quad=\text { Fungsi } \text { non linier } \\
& W_{o k}=\text { Unit ke-0 dan } k \\
& \sum_{W_{j k}} z j=\text { Jumlah unit tersembunyi ke- } j \\
& \text { Bobot awal }
\end{aligned}
$$

Kemudian dihitung koreksi nilai bobot yang kemudian akan digunakan untuk memperbaharui nilai $\Delta w j k: w j k=\alpha \delta k z j$

Hitung koreksi nilai bias yang kemudian akan adigunakan untuk memperbaharui nilai

$$
w 0 k: \Delta w 0 k=\alpha \delta k
$$

Dan kemudian nilai $\delta k$ dikirim ke neuron pada lapisan sebelumnya

Langkah 7: Setiap unit output $y_{k}$ (dari unit ke-1 sampai unit ke=m, $j=1$, menerima pola target $t_{k}$ lalu informasi kesalahan lapisan output $\left(\delta_{k}\right)$ dihitung. $\delta_{k}$ dikirim ke lapisan di bawahnya dan digunakan untuk menghitung besar koreksi bobot dan bias $\left(\Delta w_{o k}\right)$ antara lapisan tersembunyi dengan lapisan outputnya :

$$
\begin{aligned}
& \delta_{\mathrm{k}}=\left(\mathrm{t}_{\mathrm{k}}-\mathrm{y}_{\mathrm{k}}\left(w_{o k}+\sum z_{j} w_{j k}\right)_{j=1}^{p}\right. \\
& \Delta w_{j k}=\alpha \delta_{\mathrm{k}} \mathrm{Z}_{\mathrm{j}} \\
& \Delta w_{o k}=\alpha \delta_{\mathrm{k}} \\
& \text { Di mana : } \\
& \delta_{k} \quad=\text { Informasi tentang kesalahan pada unit } \mathrm{y}_{\mathrm{k}} \text { yang disebarkan kembali ke } \\
& \text { unit tersembunyi. } \\
& t_{k}=\text { Output vektor target ke- } k \\
& Y_{k} \quad=\text { Unit output ke-k } \\
& f \quad=\text { Fungsi non linier } \\
& W_{o k} \quad=\text { Unit input ke-0 dan } k \\
& \sum Z_{j}=\text { Jumlah unit tersembunyi ke-j } \\
& W_{j k} \quad=\text { Bobot awal } \\
& \Delta W_{j k} \quad=\text { Perubahan bobot }
\end{aligned}
$$




$$
\begin{array}{ll}
\alpha & =\text { Kecepatan pembelajaran (learning rate) } \\
\Delta W_{o k} & =\text { Perubahan bobot awal }
\end{array}
$$

Untuk tiap hidden neuron $(Z j, j=1,2,3, \ldots, p)$ :

$$
\delta_{-} i n_{j}=\sum_{k=1}^{m} \delta_{k} W_{j k}
$$

Kemudian nilai tersebut dikalikan dengan nilai turunan dari fungsi aktivasi untuk menghitung informasi kesalahan: $\delta j=\delta \_$in $j$

$f^{\prime}\left(z_{-}\right.$inj $)$

Hitung koreksi nilai bobot yang kemudian digunakan untuk memperbaharui vij:

$\Delta v i j=\alpha \delta j x i$

Dan hitung nilai koreksi bias yang kemudian digunakan untuk memperbaharui nilai

$v 0 j: \Delta v 0 j=\alpha \delta j$

Memperbaharui nilai bobot dan nilai bias:

Langkah 8: Tiap nilai bias dan bobot $(j=0, \ldots, p)$ pada output neuron $(Y k, k=1,2,3, \ldots, m)$ diperbaharui:

$w j k($ baru $)=w j k($ lama $)+\Delta v i j$

$V i j($ baru $)=v i j($ lama $)+\Delta v i j$

Langkah 9: Menguji apakah kondisi berhenti sudah terpenuhi. Kondisi berhenti ini terpenuhi jika nilai kesalahan yang dihasilkan lebih kecil dari nilai kesalahan referensi (Giawa D.I., 2017)

Dengan menstransformasi ini maka data terkecil akan menjadi 0.1 dan data terbesar akan menjadi 0.9. Maka data pada tabel 4.1 diatas setelah ditransformasikan hasilnya dapat ditunjukan pada tabel tabel 4.2 yang nantinya dipakai sebagai data pelatihan Bacpropagation. .

Tabel. 2. Hasil Normalisasi Sampel Data Input dan Output Prediksi Prestasi Siswa

\begin{tabular}{cccccc}
\hline $\begin{array}{c}\text { No } \\
\text { Res }\end{array}$ & B.Ind (x1) & B.Ing (x2) & MTK (x3) & IPA (x4) & Rata-rata (t) \\
1 & 0,6559 & 0,5903 & 0,5000 & 0,6217 & 0,5904 \\
2 & 0,8186 & 0,9000 & 0,9000 & 0,8826 & 0,8991 \\
\hline 3 & 0,6017 & 0,5903 & 0,5000 & 0,5870 & 0,5643 \\
\hline 4 & 0,9000 & 0,6161 & 0,5400 & 0,5522 & 0,6687 \\
5 & 0,6288 & 0,5903 & 0,6200 & 0,6565 & 0,6165 \\
6 & 0,6017 & 0,5387 & 0,1000 & 0,5348 & 0,4470 \\
7 & 0,6559 & 0,4871 & 0,4000 & 0,5348 & 0,5122 \\
8 & 0,7644 & 0,5903 & 0,1000 & 0,7087 & 0,5600 \\
9 & 0,6288 & 0,3839 & 0,3000 & 0,3783 & 0,4078 \\
10 & 0,7102 & 0,6935 & 0,1000 & 0,6217 & 0,5557
\end{tabular}




$\begin{array}{llllll}11 & 0,6559 & 0,5903 & 0,2000 & 0,4478 & 0,4817 \\ 12 & 0,7102 & 0,6419 & 0,1000 & 0,7087 & 0,5600 \\ 13 & 0,7102 & 0,5387 & 0,2000 & 0,6217 & 0,5252 \\ 14 & 0,4797 & 0,4097 & 0,1000 & 0,3365 & 0,3148 \\ 15 & 0,5990 & 0,5697 & 0,3920 & 0,5487 & 0,5235 \\ 16 & 0,7102 & 0,4871 & 0,1000 & 0,4478 & 0,4426 \\ 17 & 0,6559 & 0,5000 & 0,2600 & 0,4652 & 0,4687 \\ 18 & 0,7102 & 0,5387 & 0,1000 & 0,6217 & 0,5035 \\ 19 & 0,1000 & 0,1000 & 0,1000 & 0,3783 & 0,0991 \\ 20 & 0,4932 & 0,4355 & 0,3000 & 0,2739 & 0,3557\end{array}$

Arsitektur jaringan yang akan dibentuk adalah 4-2-1, di mana jumlah unit pada lapisan input adalah 4. Jumlah unit pada lapisan tersembunyi (hidden layer) adalah 2. Jumlah unit pada lapisan output adalah 1 Arsitektur jaringannya seperti dibawah ini :

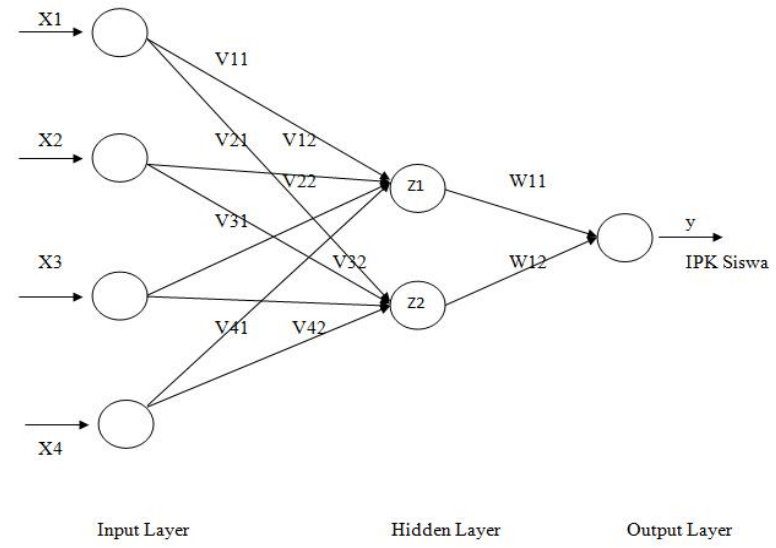

\section{Gambar Arsitektur JST untuk Prediksi Prestasi Siswa}

Dari tabel 2 didapatkan bahwa:

Data input Nomor Responden 1: $X_{1}=0,6559, X_{2}=0,5903, X_{3}=0,5000$ dan $X_{4}=$ 0,6217 dan $T=[0,5904]$

Penyelesaian :

\section{Langkah 0}

Inisialisasi semua bobot dengan bilangan acak kecil.

1. Inisialisasi bobot pada hidden layer

Untuk membentuk Jaringan Syaraf Tiruan, terlebih dahulu dilakukan inisialisasi bobot awal. Bobot awal yang menghubungkan simpul-simpul pada lapisan input dan lapisan tersembunyi untuk arsitektur diatas $V i j$ dipilih secara acak. Demikian pula bobot awal yang menghubungkan simpul-simpul pada lapisan tersembunyi dan lapisan output 
hidden layer :

juga dipilih secara acak dari bilangan random. Berikut adalah data bobot dari

Tabel 3 Bobot Yang Diberikan dari Input Layer ke Hidden Layer dan Bias

\begin{tabular}{|l|l|l|}
\hline In & \multicolumn{1}{|c|}{$\mathbf{Z}_{\mathbf{1}}$} & \multicolumn{1}{c|}{$\mathbf{Z}_{\mathbf{2}}$} \\
\hline $\mathbf{X}_{\mathbf{1}}$ & 4.7457 & 4.7786 \\
\hline $\mathbf{X}_{\mathbf{2}}$ & -5.6246 & 4.8679 \\
\hline $\mathbf{X}_{\mathbf{3}}$ & 1.9958 & -4.7393 \\
\hline $\mathbf{X}_{\mathbf{4}}$ & -4.3897 & 0.7256 \\
\hline $\mathbf{B} 1$ & -1.3499 & 0.4567 \\
\hline
\end{tabular}

Bobot dari hidden layer ke output layer penulis ambil dari matlab. Adapun nilai bobot dapat dilihat pada tabel 4.3

\section{Langkah 1}

Jika kondisi penghentian belum terpenuhi, lakukan langkah 2 - 9

1. Bobot pada satu output layer

Bobot ini adalah bobot yang terdapat pada hidden layer menuju output layer (Wjk). Nilai diambil dari bilangan acak dan akan diperbaiki saat proses perambatan balik, bobot pada output layer.

Tabel 4 Bobot Yang Diberikan dari Hidden Layer ke Output Layer

\begin{tabular}{|l|l|}
\hline & \multicolumn{1}{|c|}{$\mathbf{Y}$} \\
\hline$Z_{1}$ & 0.9150 \\
\hline$Z_{2}$ & 0.9298 \\
\hline B2 & -0.6848 \\
\hline
\end{tabular}

Diketahui :

$$
\begin{array}{llllll}
X_{1}=0.6559 & X_{2}=0.5903 & X_{3}=0.5000 & X_{4}=0.6217 \\
V_{11}=4.7457 & V_{12}=4.7786 & V_{21}=-5.6246 & V_{22}=4.8679 & V_{31}=1.9958 \\
V_{32}=-4.7393 & V_{41}=-4.3897 & V_{42} .=0.7256 & W_{11}=0.9150 & W_{12}=0.9298 \\
\theta_{3}=-1.3499 & \theta_{4}=0.4567 & \theta_{5}=-0.6848 & \alpha=0.2 & \mathrm{Yd}=0
\end{array}
$$

\section{Langkah 2}

Untuk setiap pasang data pelatihan, lakukan langkah 3 - 8

Fase I: Propagasi Maju

\section{Langkah 3}

Tiap unit masukkan menerima sinyal dan meneruskan ke unit tersembunyi

\section{Langkah 4}

Hitung semua keluaran di unit tersembunyi $\left(\mathrm{Z}_{\mathrm{j}}\right)$ :

Pada tahapan perambatan maju ini dilakukan perhitungan bobot-pada masing-masing layer menggunakan funggi aktivasi sigmoid, langkah-langkahnya sebagai berikut: 
a. Setiap unit input $\left(X_{i, i}=1,2,3, \ldots, \mathrm{p}\right)$ menerima sinyal $X_{i}$ dan meneruskan sinyal tersebut kesemua unit pada hidden layer.

b. Setiap unit tersembunyi $\left(X_{i}, i=1,2,3, \ldots\right.$, p) menjumlahkan bobot sinyal dengan input dengan persamaan rumus $(2)$ berikut.

$$
\begin{aligned}
& Z_{-} \text {net } 1=V_{j 11}+\left(X_{1} * Z_{11}\right)+\left(X_{2} * Z_{12}\right)+\left(X_{3} * Z_{13}\right)+\left(X_{4} * Z_{14}\right) \\
& =-1,3499+(0,6559 * 4,7457)+(0,5903 *-5,6246)+(0,5000 * 1,9958)+(0,6217 *-4,3897) \\
& =-3,2887 \\
& Z_{\text {nnet }} 2=V_{j 12}+\left(X_{1} * Z_{21}\right)+\left(X_{2} * Z_{22}\right)+\left(X_{3} * Z_{23}\right)+\left(X_{4} * Z_{24}\right) \\
& =0,4567+(0,6559 * 4,7789)+(0,5903 * 4,8679)+(0,5000 *-4,7393)+(0,6217 * 0,7256) \\
& =4,5463 \\
& \begin{array}{ll}
Z_{j} & =f^{l}\left(z \_n e t_{j}\right)=\frac{1}{1+e^{-z_{-} n t_{j}}} \\
Z_{1} & =\frac{1}{1+e^{-(-3,2887)}}=0,0360 \\
Z_{2} & =\frac{1}{1+e^{-(4,5463)}}=0,9895
\end{array}
\end{aligned}
$$

\section{Langkah 5}

Hitung keluaran unit output ( $\left.y_{k}\right)$ dengan rumus (5):

Jaringan memiliki 1 unit output y, maka:

$$
\begin{gathered}
y_{-} n e t_{1}=\sum_{j=1}^{1} z_{j} w_{k j} \\
=0,6848+(0,0360 * 0.9150)+(0,9895 * 0.9298) \\
=(0,2681) \\
y=f\left(y_{\text {net }}\right) \frac{1}{1+e^{-y_{n e t}}}=0,5666 \\
y_{l}=f\left(y_{\text {net }}\right) \frac{1}{1+e^{-(0,2681)}}=0,
\end{gathered}
$$

Tahap II : Umpan Mundur (Backward Propagation)

\section{Langkah 6}

Hitung faktor $\delta$ di unit output $\left(y_{k}\right)$ dengan rumus (8):

$$
\delta_{k}=\left(t_{k}-y_{k}\right) f^{\prime}\left(y_{\text {net } k}\right)=\left(t_{k}-y_{k}\right) y_{k}\left(1-y_{k}\right)
$$

Karena jaringan hanya memiliki 1 unit output, maka:

$\left.\delta_{1}=(\mathrm{t}-\mathrm{y}) \mathrm{y}(1-\mathrm{y})=(0,5904-0,5666)(0,5666)(1-0,5666)\right)=0,0058$

Kesimpulan : Pada langkah ke 6 sudah didapatkan output aktual yang diharapkan, jika dilihat dengan fungsi threshold yakni $f(n e t)=\left\{\begin{array}{l}1 \text { jika net }>\theta \\ 0 \text { jika net } \leq \theta\end{array}\right\}$, maka data Nilai responden 1 sudah dapat dikenali. Karena nilai $\delta_{1}$ menghasilkan nilai yaitu $[0,0058]$.

Selanjutnya kita lakukan perubahan bobot $w_{j k}=w_{j k}$ dengan $(\alpha=0.5)$ maka dapat dihitung dengan persamaan sebagai berikut: 


$$
\begin{aligned}
& \Delta W_{11}=0,5(0,0058)(0,0360)=0,0001 \\
& \Delta W_{12}=0,5(0,0058)(0,9895)=0,00029
\end{aligned}
$$

\section{Langkah 7}

Hitung penjumlahan kesalahan dari unit tersembunyi $(\delta)$ dengan rumus $(8)$ :

Jaringan memiliki 1 unit output, maka:

$$
\begin{aligned}
& \delta_{-} \text {net }_{1}=(0,0058)+(0.9150) \quad=0,0053 \\
& \delta \text { net }_{2}=(0,0058)+(0.9298) \quad=0,0054
\end{aligned}
$$

Untuk menghitung informasi error, kalikan nilai ini dengan turunan dari fungsi aktivasinyal dengan rumus :

$$
\delta_{j}=\delta_{\text {net } j} f^{l}\left(z_{\text {net } j}\right)=\delta_{\text {net } j} z_{j}\left(1-z_{j}\right)
$$

$\delta_{1}=0,0053(0,0360)(1-0,0360)=0,0002$

$\delta_{2}=0,0054(0,9895)(1-0,9895)=0,0001$

Kemudian hitung koreksi bobot dengan rumus (10)

$$
\begin{array}{ll}
\Delta V_{11}=\alpha \delta_{j} x_{i} \\
\Delta V_{12} & =\alpha \delta_{j} x_{i} \\
\Delta V_{21} & =\alpha \delta_{j} x_{i} \\
\Delta V_{22} & =\alpha \delta_{j} x_{i} \\
\Delta V_{31} & =\alpha \delta_{j} x_{i} \\
\Delta V_{32} & =\alpha \delta_{j} x_{i} \\
\Delta V_{41} & =\alpha \delta_{j} x_{i} \\
\Delta V_{42} & =\alpha \delta_{j} x_{i}
\end{array}
$$

$$
\begin{aligned}
& \Delta V_{j i}=\alpha \delta_{j} x_{i} \\
= & 0,5 * 0,0002 * 0,6559 \\
= & 0,5 * 0,0001 * 0,6559 \\
= & 0,5 * 0,0002 * 0,5903 \\
= & 0,5 * 0,0001 * 0.5903 \\
= & 0,5 * 0,0002 * 0,5000 \\
= & 0,5 * 0,0001 * 0,5000 \\
= & 0,5 * 0,0002 * 0,6217 \\
= & 0,5 * 0,0001 * 0.6217
\end{aligned}
$$$$
=0,0001
$$$$
=0.0000
$$$$
=0.0001
$$$$
=0.0000
$$$$
=0.0001
$$$$
=0.0000
$$$$
=0.0001
$$$$
=0.0000
$$

Tabel 5 Perubahan Ke Unit Tersembunyi

$\begin{array}{ccc}\text { Var } & Z 1 & Z 2 \\ X 1 & 0,0001 & 0,0000 \\ X 2 & 0,0001 & 0,0000 \\ X 3 & 0,0001 & 0.0000 \\ X 4 & 0,0001 & 0,0000\end{array}$

Tahap III : Peng-update-an bobot

\section{Langkah 8}

Hitung semua perubahan bobot

Untuk perubahan bobot unit output dilakukan dengan rumus (11):

$$
w_{l}=w_{k j} w_{j k}(\text { baru }) \quad=w_{j k}(\text { lama })+\Delta w_{j k}
$$

$$
w_{j k}=w_{k j} w_{j k} \text { (baru) } \quad=w_{j k}(\text { lama })+\Delta w_{j k}
$$




$$
\begin{array}{cc}
=0,9150+0,0002 & =0,9152 \\
w_{2}=w_{k j} w_{j k}(\text { baru }) & =w_{j k}(\text { lama })+\Delta w_{j k} \\
=0,9298+0,0001 & =0,9299
\end{array}
$$

Tabel 6 Tabel Bobot Baru

\begin{tabular}{|l|l|}
\hline $\mathbf{W 1}$ & 0.9152 \\
\hline $\mathbf{W 1}$ & 0.9299 \\
\hline
\end{tabular}

Untuk menghitung perubahan bobot baru pada hidden layer maka digunakan formula rumus (12) sebagai berikut:

$$
v i j(\text { baru })=v i j(\text { lama })+\Delta v i j
$$

$$
\begin{array}{lll}
V 11 \text { (baru) } & =v i j \text { (lama) }+\Delta v i j & \\
& =4,7457+0,0001 & =4,7458 \\
V 12 \text { (baru) } & =v i j(\text { lama })+\Delta v i j & \\
& =4,7786+0.0000 & =4,7786 \\
V 21 \text { (baru) } & =v i j(\text { lama })+\Delta v i j & \\
& =-5,6246+0.0001 & =-5,6245 \\
V 22 \text { (baru) } & =v i j \text { (lama) }+\Delta v i j & =4,8679+0.0000=4,8679 \\
V 31 \text { (baru) } & =v i j \text { (lama) }+\Delta v i j & =1,9958+0,0001=1,9959 \\
V 32 \text { (baru) } & =v i j \text { (lama) }+\Delta v i j & =-4.7393+0.0000=-4,7393 \\
V 41 \text { (baru) } & =v i j \text { (lama) }+\Delta v i j & =-4,3897+0.0001=-4,3896 \\
V 42 \text { (baru) } & =v i j \text { (lama) }+\Delta v i j & =0.7254+0.0001=0,7255
\end{array}
$$

Tabel 7 Tabel Bobot Baru Pada Hidden Layer

\begin{tabular}{|r|r|r|}
\cline { 2 - 3 } \multicolumn{1}{c|}{} & Z1 & Z2 \\
\hline $\mathrm{X} 1$ & 4,7458 & 4,7786 \\
\hline $\mathrm{X} 2$ & $-5,6245$ & 4,8679 \\
\hline $\mathrm{X} 3$ & 1,9959 & $-4,7393$ \\
\hline $\mathrm{X} 4$ & $-4,3896$ & 0,7255 \\
\hline
\end{tabular}

Tahapan ini dikatakan epoch I pada data Responden 1, di mana proses algoritma Bacpropagation ini belum mencapai error yang diinginkan, oleh sebab itu pelatihan jaringan harus dilakukan perulangan dimulai dari langkah 2 sampai error yang dihasilkan sesuai dengan yang diharapkan. Hasil sementara perubahan dari perubahan bobot yang terjadi pada data Responden 1 dapat dilihat pada tabel 4.11.

Tabel 8 Tabel Persentase Target Dengan Output Aktual

\begin{tabular}{|c|c|c|c|c|c|c|c|}
\hline $\begin{array}{c}\text { No } \\
\text { Res }\end{array}$ & X1 & X2 & X3 & X4 & T & $\boldsymbol{Y}$ & \% \\
\hline 1 & 0,655 & 0,590 & 0,500 & 0,621 & 0,590 & 0,006 & $\mathbf{8 6 , 8}$ \\
\hline
\end{tabular}


Karena hasil sementara ini masih sangat jauh dari target yang diharapkan, maka, untuk pelatihan jaringan Bacpropagation dilakukan perulangan sampai output yang dihasilkan sesuai dengan Target yang diharapkan.

Dari hasil pengolahan dan perancangan menggunakan Jaringan Syaraf Tiruan dengan metode Bacpropagation, maka dapat dilihat hubungan bahwa Jaringan Syaraf Tiruan bisa digunakan untuk melakukan peramalan prestasi siswa data input pola 40 data transformasi dibagi yang dibagi menjadi data pelatihan sebanyak 20 data dan data pengujian sebanyak 20 data. Hasil dari proses pengolahan data di atas didapatkan nilai update bobot antara input ke hidden layer yang digunakan untuk iterasi data selanjutnya sehingga diperoleh output actual yang diharapkan.

Hasil.

Berdasarkan tabel 8 diperoleh hasil dari pengolahan data responden 1 adalah Bahasa Indonesia (x1) sebesar 0,6559, Bahasa Inggris (x2) 0,5903, Matematika (x3) 0,5000, IPA (x4) 0,6217 , Target (t) 0,5904 dan outputnya 0,0058. Maka persentase yang diperoleh oleh responden 1 adalah sebesar $86,82 \%$. Dengan persentase yang diperoleh tersebut maka responden 1 dinyatakan berprestasi.Bagian ini menyajikan hasil penelitian.

\section{SIMPULAN}

Setelah melakukan pelatihan dan pengujian serta implementasi dengan menggunakan software Matlab R2011b terhadap data nilai siswa SMKN 1 Bunga Raya, maka dapat diambil beberapa kesimpulan sebagai berikut :

1. Dengan menggunakan Jaringan Syaraf Tiruan dengan algoritma Backpropagatian proses prediksi lebih cepat, akurat, meminimalisir kesalahan dan bisa menggunakan teknologi komputer. Serta mudah dalam pengembangannya.

2. Dapat menganalisis faktor menyebabkan kemerosotan prestasi siswa

3. Aplikasi Jaringan Syaraf Tiruan dapat memprediksi prestasi siswa pada mata pelajaran, Bahasa Indonesia, Bahasa Ingris, Matematika dan IPA dengan algoritma Backpropagation dan penggunaan tools Matlab R2011b, dengan tingkat akurasi mendekati 100\%.

Model Jaringan Syaraf Tiruan dapat memprediski prestasi siswa pada Mata Pelajaran Ujian Sekolah.

\section{UCAPAN TERIMAKASIH}

1. Bapak H. Herman Nawas selaku Ketua Yayasan Perguruan Tinggi Komputer (YPTK) Padang yang telah memberikan dukungan baik secara moril dan spritual dalam menyelesaikan studi Program Magister Ilmu Komputer pada Universitas Putra Indonesia "YPTK" Padang.

2. Bapak Prof. Dr. Sarjon Defit, S.Kom, M.Sc. selaku Rektor Universitas Putra Indonesia "YPTK" Padang yang telah memberikan dukungan baik secara moril dan spritual dalam menyelesaikan studi Program Magister Ilmu Komputer pada Universitas Putra Indonesia "YPTK" Padang.

3. Bapak Dr. Julius Santony, S.Kom, M.Kom. selaku Dekan Fakultas Ilmu Komputer Universitas Putra Indonesia "YPTK" Sekaligus pembimbing II yang telah banyak membantu dan memberi arahan dalam menyelesaikan Jurnal ini.

4. Bapak Dr. Ir. Gunadi Widi Nurcahyo, M.Sc. selaku Ketua Program Studi Magister Ilmu Komputer Universitas Putra Indonesia "YPTK" sekaligus pembimbing I yang telah banyak membantu dan memberi arahan dalam menyelesaikan Tesis ini. 
5. Seluruh Dosen Pascasarjana Magister Ilmu Komputer yang telah berbagi ilmu selama pendidikan di Universitas Putra Indonesia "YPTK" Padang.

6. Keluarga Besar SMK Negeri 1 Bunga Raya telah memberikan dukungan berupa moril dalam menyelesaikan studi Program Magister Ilmu Komputer pada Universitas Putra Indonesia "YPTK" Padang.

7. Keluarga Besar SMK Negeri 2 Pinggir yang telah memberi dukungan dan motivasi dalam menyelesaikan studi Program Magister Ilmu Komputer pafa Universitas Putra Indonesia "YPTK" Padang.

8. Orang Tua Tercinta Ayah (Zalmi Fakri), Ibu (Asnadiar) yang senantiasa mendoa'kan kepada ananda, Suami (Irrizon, S.Hi) dan anak- anak tercinta (Indana Halwah Raqiqah, Rameyzha Elya Raqiqah dan Fayrel Atharizzon Calief)

9. Teman - teman terutama Gang Mayat yang senantiasa memberikan semangat dan berbagi ilmu serta pengalamannya.

10. Rekan-rekan M.Kom angkatan XXVIII-B yang selalu memberikan semangat dan motivasi dalam menyelesaikan tesis ini.

\section{DAFTAR PUSTAKA}

Anike M., Suyoto., and Ernawati . (2012). "Pengembangan Sistem Jaringan Syaraf Tiruan dalam Memprediksi Jumlah Dokter Keluarga menggunakan Backpropagation".

Anwar B. (2011) "Penerapan Algoritma Jaringan Syaraf Tiruan Backpropagation dalam Memprediksi Tingkat Suku Bunga Bank".

Berutu R. ( 2017 ). "Implementasi Jaringan Syaraf Tiruan untuk Memprediksi Penjualan Kosmetik Decorative dengan Metode Backpropagation".

Gupta A., and Shreevastava M. ( 2011 ). "Medical Diagnisis using Backpropagation Algorithma":Internationla Journal, ISSN:2250-2459.

Kusmaryanto S. ( 2014 ). "Jaringan Syaraf Tiruan Backpropagation untuk Pengenalan Wajah Metode Ekstraksi Fitur Berbasis Histogram".

Madontang Z.A. ( 2013 ). " Jaringan Syaraf Tiruan dengan Algoritma Backpropagation untuk menentukan kelulusan Sidang Skripsi”.

Malik B.A., Naqash A., and Bhat. ( 2016). "Backpropagation Artificial Neural Network for Determination of Glocose Concentration from Near-Infrared Spectra": India ICACCI, September 21-24.

Mustaqim J.R., Ratianingsih R., and Lusiyanti. ( 2017). "Prediksi Kualitas Air Bersih PDAM Kota Palu Menggunakan Metode Backpropagation".

Pratama R.A., and Anifah L. ( 2011). "Peramalan Beban Listrik Jangka Panjang Provinsi D.I Yogjakarta menggunakan Neural Network Bacpropagation".

Setiabudi D. ( 2015). "Sistem Informasi Peramalan Beban Listrik Jangka Panjang di Kabupaten Jember Menggunakan Jaringan Syaraf Tiruan Backpropagation": ISSN:2476-9754.

Siang J.J. (2004). "Jaringan Syaraf Tiruan \& Pemogramannya Menggunakan Matlab": Andi.

Tanjung D.H. (2015). "Jaringan Syaraf Tiruan dengan Backpropagation untuk Memprediksi Penyakit Asma" : ISSN: 2354-5771.

Tisan A., and Chin J. ( 2016). "An End User Platform For FPGA-Based Design and Rapid Prototyping of Feed Forward Artificial Neural Networks with on-Chip Backpropagation Learning".

Wuryandari M.D., and Afrianto I. ( 2012 ). "Perbandingan Metode Jaringan Syaraf Tiruan Backpropagation dan Learning Vector Quantization pada Pengenalan Wajah".

Yani E. ( 2005 ). "Pengantar Jaringan Syaraf Tiruan" 